\title{
KEANEKARAGAMAN DAN DISTRIBUSI BENIH IKAN DI BEBERAPA TIPE HABITAT SUNGAI BATANGHARI, JAMBI
}

\author{
Syarifah Nurdawati \\ Peneliti pada Balai Riset Perikanan Perairan Umum, Palembang
}

Teregristrasi I tanggal: 2 Agustus 2005; Diterima setelah perbaikan tanggal: 8 Juni 2007; Disetujui terbit tanggal: 6 Juli 2007

\begin{abstract}
ABSTRAK
Penelitian keanekaragaman dan distribusi benih ikan di beberapa tipe habitat Sungai Batanghari, Jambi telah dilakukan dengan tujuan untuk mengetahui keanekaragaman benih ikan, habitat, dan distribusi. Penelitian ini dilakukan di perairan daerah aliran Sungai Batanghari yang terletak di Kodya Jambi (Danau Teluk dan Danau Buluran Kenali) dan Kabupaten Batanghari (Danau Kaos, Sungai Terap, Sungai Lubuk Ruso, dan Sungai Pijoan). Penelitian dilakukan pada waktu air surut setelah banjir besar. Contoh benih ikan dikumpulkan dari hasil percobaan penangkapan dan tangkapan nelayan kemudian diidentifikasi. Larva yang belum dapat diidentifikasi dipelihara terlebih dahulu di dalam hapa, danau, dan akuarium. Hasil penelitian menunjukkan bahwa terdapat 90 jenis benih ikan yang termasuk ke dalam 44 genus, 18 famili, 5 sub ordo dari Ordo Perciformes (Percoidei, Gobioidei, Anabantoidei, Channoidei, dan Mastacembeloidei) dan 6 ordo (Osteoglosiformes, Cypriniformes, Siluriformes, Perciformes Cyprinodontiformes, dan Tetraodontiformes). Famili Cyprinidae mendominasi jenis yang ditemukan yaitu 40 jenis, diikuti oleh Famili Bagridae 15 jenis. Pada waktu air banjir kualitas air di lokasi penelitian menunjukkan kondisi yang baik untuk kehidupan benih ikan dan pada saat air surut setelah banjir kualitas air menurun. Habitat benih ikan di lokasi pengamatan merupakan habitat sementara dan setelah kualitas air menurun benih-benih ikan melakukan ruaya menuju ke sungai utama dan seterusnya beruaya ke bagian hulu sungai.
\end{abstract}

\section{KATAKUNCl: Keanekaragaman, benih ikan, habitat, distribusi, Sungai Batanghari}

\section{ABSTRACT: Study on biodiversity and distribution of fish fry in some type of habitats of Batanghari River basin, Jambi. By: Syarifah Nurdawati}

\begin{abstract}
Study on biodiversity and distribution of fish fry in some type of habitats of Batanghari River basin, Jambi was conducted to observe the kind of fish species, habitat, and the distribution. Location of the experiment were Batanghari River in Kodya Jambi (Teluk Lake and Buluran Kenali Lake and Kabupaten Batanghari (Terap River, Lubuk Ruso River, and Pijoan River). The study used survey method for every lowest fluktuation water. Larva and seeds fish were collected from fishermen and identified. For larvae were collected and held in aquaria or in hapas in lake before identified. The results show that 90 species seed fish were collected, there are 44 genus, 18 familiy, 5 sub ordo from Ordo Perciformes (Percoidei, Gobioidei, Anabantoidei, Channoidei, dan Mastacembeloidei) and 6 Ordo (Osteoglosiformes, Cypriniformes, Siluriformes, Perciformes Cyprinodontiformes, dan Tetraodontiformes), about 40 species dominated by Cyprinidae. Water quality in location was good for hight water fluctuation and bad for lowest water fluctuation. Four habitats of seed fish were not permanent habitat and in bad condition water quality, seed fish were migrating out of the floodplain and leaved for up stream of Batanghari River.
\end{abstract}

\section{KEYWORDS: $\quad$ biodiversity, first fry species, habitat, distribution, Batanghari River}

\section{PENDAHULUAN}

Propinsi Jambi dengan luas perairan umum 115.000 ha merupakan perairan yang potensial sebagai penghasil ikan. Perairan ini terletak pada ketinggian 0 sampai dengan $1.600 \mathrm{~m}$ di atas permukaan laut dengan sungai utama adalah Sungai Batanghari (Dinas Perikanan Propinsi Jambi, 1984). Di perairan ini terdapat berbagai jenis benih ikan perairan umum yang bernilai ekonomis penting dan telah pula diperdagangkan keluar daerah bahkan sampai dengan ke luar negeri seperti ke Malaysia dan Singapura (Ondara, 1968). Pemanfaatan benih ikan antara lain untuk ikan budi daya seperti benih ikan jelawat (Leptobarbus hoevenii), toman (Channa micropeltes), ringo (Thynnichthys thynnoides), baung (Mystus nemurus), dan tembakang (Helostoma temminckii), untuk ikan hias antara lain ikan botia (Botia macracanthus), bentulu (Barbichthys laevis), lais (Kryptopterus spp.), johar (Luciosoma setigerum), baung kembang (Leiocassis leiacanthus), coklat gurami (Spaerichthys osphromenoides), serta beberapa jenis dari ikan rasbora (Rasbora spp.) (Dinas Perikanan Propinsi Jambi, 1989; Dinas Perikanan Propinsi Jambi, 1993; Nurdawati \& Said 1995a). 
Habitat benih ikan perairan umum Jambi sebagian besar terletak di daerah aliran Sungai Batanghari bagian tengah di mana pada umumnya merupakan daerah banjiran. Berdasarkan pada Utomo \& Nasution (1995) tipe perairan daerah aliran Sungai Batanghari bagian tengah ditandai dengan perairan yang berarus tenang, merupakan daerah banjiran, di kanan kiri sungai banyak terdapat hutan rawang dan lebak kumpai. Tipe perairan ini dimulai dari Desa Sogo (Kecamatan Kumpeh) sampai dengan ke Muara Tebo (Kabupaten Bungo Tebo). Kegiatan penangkapan ikan merupakan mata pencaharian utama, produksi perikanan tangkap tinggi dan jenis ikan lebih beragam. Selanjutnya, dikatakan bahwa habitat benih ikan dan ikan hias dimulai dari Desa Terusan di Kabupaten Batanghari sampai dengan ke Sungai Kumpeh dan Danau-danau oxbow yang terletak di Kabupaten Batanghari dan Kodya Jambi. (Dinas Perikanan Propinsi Jambi, 1984) Induk-induk ikan ditemukan di Sungai Batanghari mulai dari Muara Tembesi sampai dengan ke Teluk Kayu Putih. Utomo \& Zahri (1995) mengatakan bahwa habitat induk ikan dan habitat benih ikan berada di daerah aliran Sungai Batanghari bagian tengah.

Penelitian-penelitian benih ikan perairan umum belum banyak dilakukan, hanya ada beberapa jenis benih ikan ekonomis penting yang telah diteliti antara lain benih ikan sidat (Sriati \& Sulistiono, 2000; Setiawan, 2002) dan penelitian larva ikan estuarin yang telah dilakukan oleh Wagiyo et al. (2001). Berdasarkan pada hal tersebut di atas dilakukan penelitian keanekaragaman dan distribusi benih ikan di beberapa tipe habitat Sungai Batanghari,
Jambi dengan tujuan untuk mengetahui jenis-jenis benih ikan dan distribusi di ruas Sungai Batanghari khususnya di kawasan Kodya Jambi dan Kabupaten Batanghari. Selain itu, diungkapkan pula kualitas air serta penangkapan benih ikan.

\section{BAHAN DAN METODE}

Penelitian ini dilakukan di beberapa habitat benih ikan berupa anak sungai, danau, dan genangan rawa. Stasiun pengamatan ditetapkan berdasarkan pada habitat benih ikan yaitu Danau Teluk, Danau Buluran Kenali (Kodya Jambi), Danau Kaos, Sungai Terap, Sungai Lubuk Ruso, dan Sungai Pijoan (Kabupaten Batanghari), (Gambar 1). Pengambilan contoh dilakukan setiap air surut setelah banjir yaitu bulan September, Oktober, Desember, Pebruari, Maret, dan April.

Pengambilan contoh jenis-jenis benih ikan dilakukan selama musim penghujan. Alat tangkap yang dipergunakan untuk menangkap benih ikan adalah tangguk (hand net), tangkul (portable lift nets), tabung (trap), tabok (pot trap), tabam-tabam (pot trap), dan rombong (pot trap). Penangkapan dengan alat tangkap tangguk dilakukan sendiri, sedangkan hasil tangkapan dengan alat tangkap lain di dapat dari nelayan yang melakukan penangkapan benih ikan.

Identifikasi larva dilakukan dengan cara memelihara terlebih dahulu di dalam hapa-hapa di danau dan akuarium selama 1 sampai dengan 2 minggu sampai dengan dapat

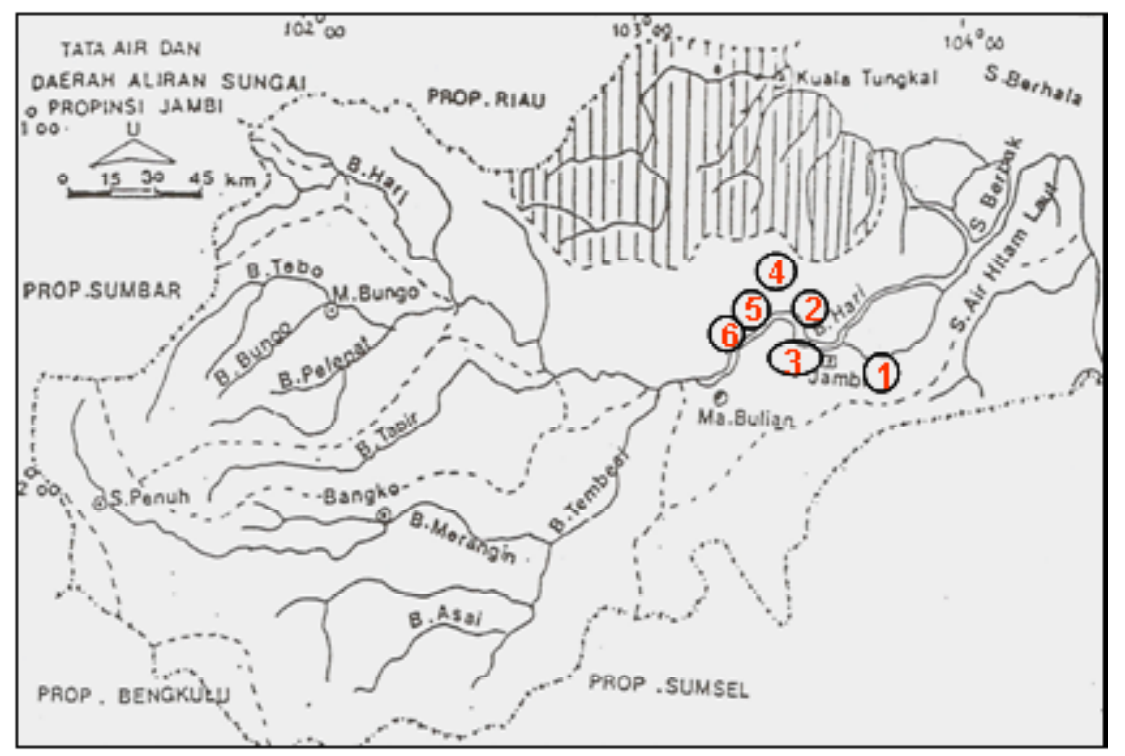

Gambar 1. Peta lokasi penelitian di daerah aliran Sungai Batanghari, Jambi.

Figure 1. Map of the location of study site in Batanghari River basin. Keterangan/Remarks: 1 = Sungai Terap; 2 = Danau Teluk; 3 = Danau Buluran Kenali; 4 = Danau Kaos; 5 = Sungai Pijoan; 6 = Sungai Lubuk Ruso 
dilakukan identifikasi. Contoh larva ikan jelawat (Leptobarbus hoevenii), seluang (Rasbora argyrotaenia), dan ikan bentulu (Barbichthys laevis) hampir sama bentuknya antara satu dengan lain sehingga untuk identifikasi larva tersebut dipelihara terlebih dahulu di hapa-hapa selama kurang lebih 2 minggu. Pemeliharaan di danau dilakukan di hapa-hapa tanpa diberi makan, sedangkan pemeliharaan di akuarium dilakukan pemberian makan dengan makanan alami antara lain moina (moina sp.).

Identifikasi jenis larva ikan dilakukan berdasarkan pada Kottelat et al. (1993); Weber \& de Beaufort (19131953); Saanin (1968). Pengamatan habitat dilakukan dengan mengukur kualitas air (APHA, 1986) di bagian permukaan dan data tinggi air di dapat dari Perum Pelabuhan Jambi. Wawancara dengan nelayan dilakukan antara lain untuk mengetahui nama-nama lokal benih ikan yang tertangkap dan jenis-jenis benih ikan yang telah diperdagangkan.

\section{HASIL DAN BAHASAN}

\section{Keanekaragaman Jenis Benih Ikan}

Hasil pengambilan contoh di stasiun-stasiun yang telah ditetapkan (Lampiran 1) didapatkan 90 jenis benih ikan yang termasuk ke dalam 47 genus, 19 famili (Tabel 1), 5 sub ordo dari Ordo Perciformes (Percoidei, Gobioidei, Anabantoidei, Channoidei, dan Mastacembeloidei) dan 6 ordo (Osteoglosiformes, Cypriniformes, Siluriformes, Perciformes,Cyprinodontiformes, dan Tetraodontiformes).

Famili Cyprinidae mendominasi jenis-jenis yang ditemukan yaitu 41 jenis, diikuti oleh Famili Siluridae 9 jenis, dan Famili Bagridae 7 jenis. Ini sesuai dengan yang dikatakan oleh Schuster \& Djajadiredja (1952) bahwa wilayah Sunda (Sumatera, Jawa, dan Kalimantan) didominasi oleh Ordo Ostariophysi (Weber \& de Beaufort, 1916); Ordo Ostariophysi pada saat ini telah berganti dengan nama Ordo Cypriniformes (Kottelat et al., 1993).

Dari ke-6 stasiun pengamatan, Danau Teluk merupakan lokasi yang paling banyak ditemukan benihbenih ikan yaitu 52 jenis kemudian diikuti oleh stasiun pengamatan Danau Kaos dan Danau Buluran Kenali (Gambar 2).

Di Danau Teluk, Sungai Pijoan, dan Danau Buluran Kenali jenis-jenis benih yang tertangkap hampir sama. Di Danau Kaos dan Sungai Terap jenis-jenis benih ikan didominasi ikan rawa seperti benih ikan tembakang (Helostoma temminckii), coklat gurami (Spaerichthys osphromenoides), cupang (Betta sp.), dan benih ikan

Tabel 1. Jumlah spesies, genus, dan famili dari benih ikan di Sungai Batanghari, Jambi

Table 1. Number of spesies, genus, and family of fish fry in Batanghari River, Jambi

\begin{tabular}{|c|c|c|c|}
\hline No. & Famili & No. & Spesies \\
\hline 1. & Notopteridae & 1 & 1 \\
\hline 2. & Cyprinidae & 19 & 41 \\
\hline 3. & Cobitidae & 2 & 5 \\
\hline 4. & Bagridae & 3 & 7 \\
\hline 5. & Siluridae & 3 & 9 \\
\hline 6. & Schilbidae & 1 & 1 \\
\hline 7. & Chacidae & 1 & 1 \\
\hline 8. & Chandidae & 1 & 2 \\
\hline 9. & Nandidae & 1 & 2 \\
\hline 10. & Pristolepididae & 1 & 2 \\
\hline 11. & Toxotidae & 1 & 1 \\
\hline 12. & Belontidae & 5 & 7 \\
\hline 13. & Helostomatidae & 1 & 1 \\
\hline 14. & Osphronemidae & 1 & 1 \\
\hline 15. & Channidae & 1 & 4 \\
\hline 16. & Mastacembelidae & 2 & 2 \\
\hline 17. & Gobiidae & 1 & 1 \\
\hline 18. & Tetraodontidae & 1 & 1 \\
\hline \multirow[t]{2}{*}{19.} & Belonidae & 1 & 1 \\
\hline & Jumlah & 47 & 90 \\
\hline
\end{tabular}




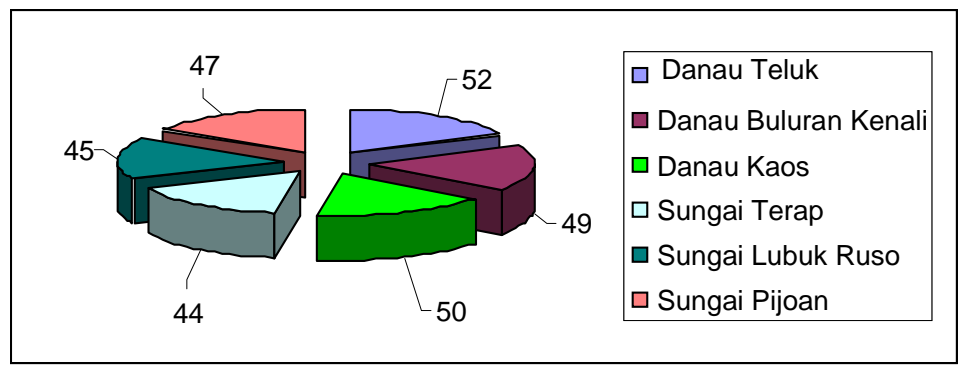

Gambar 2. Jenis-jenis benih ikan yang ditemukan di setiap lokasi pengamatan.

Figure 2. The fry fish species found in study location.

kalui (Osphronemus goramy). Benih ikan di Sungai Pijoan dan Lubuk Ruso lebih banyak tertangkap dari jenis ikan kecil yang termasuk Genus Rasbora dan Puntius (Lampiran 1).

\section{Distribusi Benih Ikan}

Siklus hidrologi sangat mempengaruhi distribusi benihbenih ikan yang berada di danau-danau dan sungai. Benih-benih ikan yang berukuran larva pada awal terjadi kenaikan air berada di pinggir-pinggir genangan-genangan yang berhubungan dengan danau-danau dan anak-anak sungai. Pada saat terjadi penurunan permukaan perairan, larva telah berukuran menjadi benih dan memasuki anakanak sungai dan danau-danau beruaya mengikuti arus menuju ke sungai utama yaitu Sungai Batanghari.

Berdasarkan pada habitat induk ikan yang terdapat di daerah aliran Sungai Batanghari, maka benih-benih ikan yang terdapat di daerah aliran Sungai Batanghari Jambi dapat dibagi atas 2 bagian yaitu ke-1 didasarkan pada tidak tertangkap induk-induk ikan dan hanya tertangkap benih ikan, ke-2 tertangkap induk dan benih ikan di lokasi yang sama (Tabel 2).

Tabel 2. Jenis-jenis benih ikan yang tidak tertangkap bersama induk ikan di masing-masing lokasi pengamatan Table 2. The species seed fish caught without broodstock in study location site

\begin{tabular}{|c|c|c|}
\hline No. & Jenis benih & Nama ilmiah \\
\hline 1. & Mentulu & Barbichthys laevis \\
\hline 2. & Wajang & Cyclocheillichthys enoplos \\
\hline 3. & Kopras & Cyclocheillichthys apogon \\
\hline 4. & Keperas & Cyclocheilichthys heteronema \\
\hline 5. & Susur batang & Epalzeorhynchus kallopterus \\
\hline 6. & Kebarau & Hampala macrolepidota \\
\hline 7. & Si hitam & Labeo chrysophekadion \\
\hline 8. & Srepang & Puntioplites waandersii \\
\hline 9. & Kelemak & Leptobarbus hoevenii \\
\hline 10. & Ringo & Thynnichthys thynnoides \\
\hline 11. & Ikan merah & Botia macracanthus \\
\hline 12. & Langli hijau & Botia hymenophysa \\
\hline 13. & Sengarat & Belodontichthys dinema \\
\hline 14. & Lais kuning & Kryptopterus schilbeides \\
\hline 15. & Lais tapa & Ompok hypophthalmus \\
\hline 16. & Lais kaca & Kryptopterus bicirrhis \\
\hline 17. & Lais & Kryptopterus mononema \\
\hline 18. & Lais & Kryptopterus hexapterus \\
\hline 19. & Lais hujan & Kryptopterus palembangensis \\
\hline 20. & Lais tima & Kryptopterus apogon \\
\hline 21. & Lais kaca & Kryptopterus minor \\
\hline 22. & Lalayang & Bagrichthys hyselopterus \\
\hline 23. & Baung lilin & Mystus bimaculatus \\
\hline 24. & Senggiring & Mystus nigriceps \\
\hline 25. & Tilan & Mastacembelus erythrotaenia \\
\hline 26. & Tilan putih & Macrognathus aculeatus \\
\hline
\end{tabular}


Benih-benih ikan yang berasal dari daerah hulu sungai di mana induk-induk hidup di bagian hulu dan menetaskan telur di bagian hilir sungai untuk seterusnya larva ikan tersebut ikut terbawa arus masuk ke danau-danau dan genangan-genangan yang tergenang secara periodik pada musim penghujan (daerah banjiran). Menurut Utomo \& Nasution (1995) habitat induk-induk ikan dan benih ikan berada di daerah aliran Sungai Batanghari bagian tengah.

Benih ikan ringo (Thynnichthys thynnoides) merupakan salah satu jenis ikan yang hanya tertangkap di danau yaitu Danau Teluk dan tidak tertangkap di lokasi lain. Nurdawati, S. \& E. Dharyati (1994) mengatakan bahwa habitat induk ikan ringo terdapat di danau-danau oxbow yang terletak di kabupaten Muaro Bungo.
Selanjutnya, Dinas Perikanan Tingkat I Jambi (1993) mengatakan bahwa ikan ringo termasuk salah satu jenis ikan yang telah mulai sulit tertangkap. Hal ini, diduga disebabkan habitat ikan ringo mulai dari ukuran benih sampai dengan ukuran induk adalah danau-danau oxbow yang luas hanya beberapa hektar.

Benih-benih ikan yang penyebaran hanya di satu lokasi di mana benih dan induk hidup di habitat yang sama (Tabel 3). Danau Teluk merupakan salah satu habitat benih ikan botia (Botia macracanthus) dan ikan jelawat (Leptobarbus hoevenii), sedangkan di Sungai Terap merupakan habitat ikan hias dari Genus Rasbora dan Genus Laubuca yang termasuk salah satu ikan hias ekonomis penting.

Tabel 3. Jenis-jenis benih ikan yang tertangkap bersama induk yang matang gonad di masing-masing lokasi pengamatan

Table 3. The species of fish seeds caught in same location with brooder fish

\begin{tabular}{|c|c|c|c|c|c|c|c|c|}
\hline No. & Jenis benih & Nama ilmiah & $\begin{array}{l}\text { Danau } \\
\text { Teluk }\end{array}$ & $\begin{array}{c}\text { Danau } \\
\text { Buluran } \\
\text { Kenali }\end{array}$ & $\begin{array}{l}\text { Danau } \\
\text { Kaos }\end{array}$ & $\begin{array}{l}\text { Sungai } \\
\text { Terap }\end{array}$ & $\begin{array}{c}\text { Sungai } \\
\text { Lubuk } \\
\text { Ruso }\end{array}$ & $\begin{array}{l}\text { Sungai } \\
\text { Pijoan }\end{array}$ \\
\hline 1. & Lampam/kepiat & $\begin{array}{l}\text { Barbodes } \\
\text { schwanenfeldii }\end{array}$ & $x$ & $x$ & $x$ & & & \\
\hline 2. & Seluang terbang & Chela laubuca & & & & $x$ & & \\
\hline 3. & Seluang pimping & Chela maassi & & & & & $x$ & $x$ \\
\hline 4. & Seluang pimping & $\begin{array}{l}\text { Parachela } \\
\text { oxygastroides }\end{array}$ & $x$ & $x$ & $x$ & & & \\
\hline 5. & Susur batang putih & $\begin{array}{l}\text { Crossocheilus } \\
\text { gnathopogon }\end{array}$ & $x$ & $x$ & $x$ & & & \\
\hline 6. & Parang-parang & $\begin{array}{l}\text { Macrochirichthys } \\
\text { macrochirus }\end{array}$ & $x$ & & & & & \\
\hline 7. & Sebaro hutan & Rasbora kalochroma & & & & $x$ & $x$ & \\
\hline 8. & Srigunting & R. caudimaculata & & & & & $x$ & \\
\hline 9. & Seluang segitiga & R. heteromorpha & & & & $x$ & $x$ & \\
\hline 10. & Seluang ridik & R. dorsiocellata & & & & & $x$ & \\
\hline 11. & Seluang biaso & R. dusonensis & & & & $x$ & & \\
\hline 12. & Teri & Rasbora sp. & & & & $x$ & $x$ & \\
\hline 13. & Seluang pantau & Rasbora argyrotaenia & $x$ & $x$ & $x$ & $x$ & $x$ & $x$ \\
\hline 14. & Strip enam/kadis & Puntius johorensis & & & & & $x$ & \\
\hline 15. & Palau & Osteochilus hasseltii & $x$ & $x$ & $x$ & & & \\
\hline 16. & Teri & Rasborichthys helfrichii & $x$ & & & & & \\
\hline 17. & Baung lilin & Mystus bimaculatus & & & & & $x$ & $x$ \\
\hline 18. & Baung & Mystus nemurus & $x$ & $x$ & $x$ & & & \\
\hline 19. & Caka-caka & Chaca bankanensis & & & & & & \\
\hline 20. & Beterung & Pristolepis fasciata & & & & & & \\
\hline 21. & Tempalo & Betta anabatoides & & & & $x$ & $x$ & $x$ \\
\hline 22. & Tempalo & Betta picta & & & & $x$ & $x$ & $x$ \\
\hline 23. & Tempalo & Betta taeniata & & & & $x$ & $x$ & $x$ \\
\hline 24. & Cupang & Trichopsis vittata & $x$ & $x$ & $x$ & $x$ & $x$ & $x$ \\
\hline 25. & Coklat gurami & $\begin{array}{l}\text { Spaerichthys } \\
\text { osphromenoides }\end{array}$ & & & & & $x$ & $x$ \\
\hline 26. & Sepat leeri & Trichogaster leerii & $x$ & $x$ & $x$ & $x$ & $x$ & $x$ \\
\hline 27. & Tembakang & Helostoma temminckii & $x$ & $x$ & $x$ & $x$ & $x$ & $x$ \\
\hline 28. & Selincah & Belontia hasselti & & & & $x$ & $x$ & \\
\hline 29. & Gabus & Channa striata & $x$ & $x$ & $x$ & $x$ & $x$ & $x$ \\
\hline 30. & Bujuk & Channa lucius & & $x$ & $x$ & $x$ & & \\
\hline 31. & Toman & Channa micropeltes & $x$ & $x$ & $x$ & & & \\
\hline 32. & Serandang & $\begin{array}{l}\text { Channa } \\
\text { pleurophthalmus }\end{array}$ & & & $x$ & $x$ & & \\
\hline
\end{tabular}


Benih-benih ikan lain yang penyebaran hanya di 1 tempat yaitu ikan seluang terbang (Chela laubuca) yang merupakan ikan hias yang banyak permintaan dan tertangkap hanya di Sungai Terap (Tabel 4).
Di samping itu, ada beberapa jenis benih yang penyebaran di seluruh lokasi pengamatan (Tabel 5). Benih-benih ikan ini ada yang bersifat migrasi seperti benih ikan dari Genus Kryptopterus yang induk hidup di Sungai Batanghari.

Tabel 4. Benih-benih ikan yag penyebaran hanya di 1 lokasi pengamatan

Figure 4. The distribution of fish seeds only in one location

\begin{tabular}{|c|c|c|c|c|c|}
\hline \multirow{2}{*}{ No. } & \multicolumn{2}{|r|}{ Jenis benih } & \multirow{2}{*}{ Danau Teluk } & \multirow{2}{*}{ Sungai Terap } & \multirow{2}{*}{$\begin{array}{c}\text { Sungai Lubuk } \\
\text { Ruso }\end{array}$} \\
\hline & Nama lokal & Nama ilmiah & & & \\
\hline 1. & Seluang terbang & Chela laubuca & & $x$ & \\
\hline 2. & Sebaro hutan & Rasbora kalochroma & & & $x$ \\
\hline 3. & Srigunting & R. caudimaculata & & & $x$ \\
\hline 4. & Seluang segitiga & R. heteromorpha & & & $x$ \\
\hline 5. & Seluang ridik & R. dorsiocellata & & & $x$ \\
\hline 6. & Seluang biaso & R. dusonensis & & $x$ & \\
\hline 7. & Strip enam/kadis & Puntius johorensis & & & $x$ \\
\hline 8. & Seluang payo & Puntius lineatus & & $x$ & \\
\hline 9. & Teri & Rasborichthys helfrichii & $x$ & & \\
\hline 10. & Tali-tali & Acanthophthalmus shelfordii & & $x$ & \\
\hline 11. & Tali-tali & Acanhtopthalmus anguillaris & & $x$ & \\
\hline
\end{tabular}

Tabel 5. Penyebaran benih-benih ikan di seluruh lokasi pengamatan

Table 5. The distribution of fish seeds in whole reseach location

\begin{tabular}{|c|c|c|c|c|c|c|c|c|}
\hline \multirow{2}{*}{ No. } & \multicolumn{2}{|c|}{ Jenis benih } & \multirow{2}{*}{$\begin{array}{l}\text { Danau } \\
\text { Teluk }\end{array}$} & \multirow{2}{*}{$\begin{array}{c}\text { Danau } \\
\text { Buluran } \\
\text { Kenali }\end{array}$} & \multirow{2}{*}{$\begin{array}{l}\text { Danau } \\
\text { Kaos }\end{array}$} & \multirow{2}{*}{$\begin{array}{l}\text { Sungai } \\
\text { Terap }\end{array}$} & \multirow{2}{*}{$\begin{array}{c}\text { Sungai } \\
\text { Lubuk } \\
\text { Ruso }\end{array}$} & \multirow{2}{*}{$\begin{array}{l}\text { Sungai } \\
\text { Pijoan }\end{array}$} \\
\hline & Nama lokal & Nama ilmiah & & & & & & \\
\hline \multirow[t]{2}{*}{1.} & Keperas & Cyclocheilichthys & & & & & & \\
\hline & & heteronema & $x$ & $x$ & $x$ & $x$ & $x$ & $x$ \\
\hline 2. & Seluang pantau & Rasbora argyrotaenia & $x$ & $x$ & $x$ & $x$ & $x$ & $x$ \\
\hline \multirow[t]{2}{*}{3.} & Lais & Kryptopterus & & & & & & \\
\hline & & hexapterus & $x$ & $x$ & $x$ & $x$ & $x$ & $x$ \\
\hline \multirow[t]{2}{*}{4.} & Lais hujan & Kryptopterus & & & & & & \\
\hline & & palembangensis & $x$ & $x$ & $x$ & $x$ & $x$ & $x$ \\
\hline 5. & Lais tima & Kryptopterus apogon & $x$ & $x$ & $x$ & $x$ & $x$ & $x$ \\
\hline 6. & Senggiring & Mystus nigriceps & $x$ & $x$ & $x$ & $x$ & $x$ & $x$ \\
\hline 7. & Baung & Mystus nemurus & $x$ & $x$ & $x$ & $x$ & $x$ & $x$ \\
\hline 8. & Cupang & Trichopsis vittata & $x$ & $x$ & $x$ & $x$ & $x$ & $x$ \\
\hline 9. & Sepat leeri & $\begin{array}{l}\text { Trichogaster leerii } \\
\text { Helostoma }\end{array}$ & $x$ & $x$ & $x$ & $x$ & $x$ & $x$ \\
\hline 10. & Tembakang & temminckii & $x$ & $x$ & $x$ & $x$ & $x$ & $x$ \\
\hline 11. & Gabus & Channa striata & $x$ & $x$ & $x$ & $x$ & $x$ & $x$ \\
\hline
\end{tabular}

\section{Karakteristik Habitat Benih Ikan}

Danau Teluk adalah sebuah danau oxbow yang hubungan air dengan Sungai Batanghari sangat erat karena limpasan air Sungai Batanghari pada saat banjir mengisi danau ini, tetapi pada musim kemarau hubungan air sangat berkurang atau putus sama sekali (Dinas Perikanan Propinsi Jambi, 1993). Pada waktu musim penghujan seluruh hutan-hutan semak belukar, sawahsawah tergenang air dan berhubungan langsung dengan
Danau Teluk (Gambar 3). Utomo \& Asyari (1999) mengatakan bahwa genangan-genangan yang luas dan banyak hutan semak belukar yang terendam air merupakan tempat perlindungan dan mencari makan bagi benih atau larva ikan. Selanjutnya, Nurdawati (2006) mengatakan bahwa tumbuhan atau semak belukar yang terendam air dalam waktu yang lama merupakan tempat menempel perifiton yang menjadi makanan bagi benih ikan. Hal ini, mungkin yang menyebabkan di Danau Teluk banyak tertangkap benih-benih ikan. 


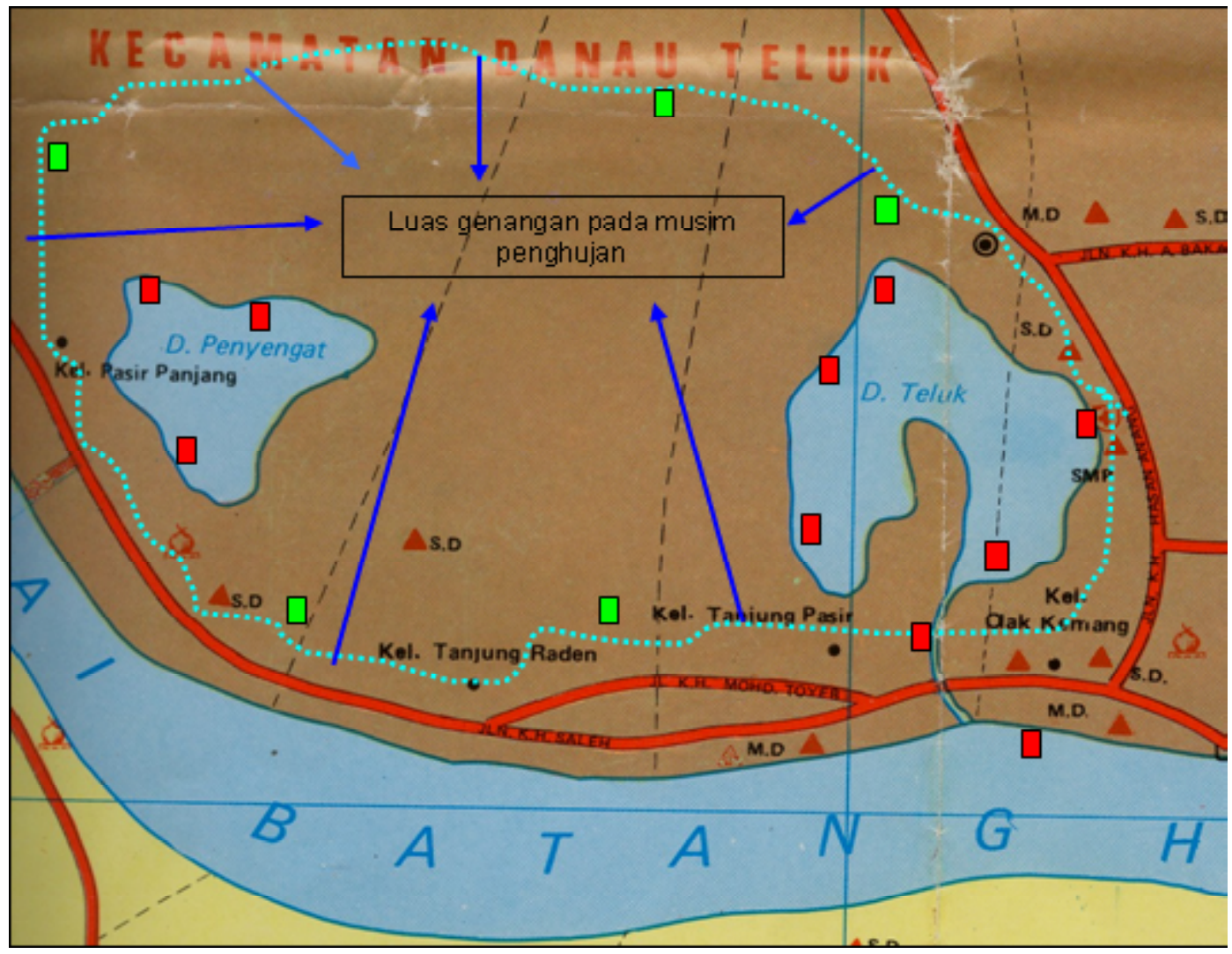

Gambar 3. Genangan-genangan Danau Teluk pada musim penghujan.

Figure 3. Floodplain of Teluk Lake in rainy season.

Keterangan/Remarks: $\square$ Penyebaran larva ikan

Penyebaran benih ikan

Seperti halnya Danau Teluk, Danau Kaos, dan Danau Buluran Kenali karakteristik hampir sama yaitu merupakan danau yang dikelilingi oleh hutan semak belukar, sawah-sawah, dan perkebunan karet yang tergenang air pada musim penghujan.

Sungai Lubuk Ruso merupakan anak Sungai Batanghari yang warna air pada musim penghujan berwarna agak keruh kecoklatan, sedangkan pada musim kemarau coklat kehitaman. Dibandingkan dengan perairan danau, jenis benih yang tertangkap terutama dari jenis Rasbora dan Betta. Meskipun pH air lebih rendah jika dibandingkan dengan perairan lain, Sungai Lubuk Ruso merupakan pusat penangkapan ikan botia (Cromobotia macracanthus).

Selama musim penghujan, antara danau, rawa, dan anak sungai telah menyatu sehingga keadaan kualitas air relatif sama (Tabel 6). Di samping itu, terdapat perairan baru yang disebut dengan genangan. Genangangenangan secara periodik ini pada umumnya terletak atau berada di sekitar pinggir sungai dan danau. Pada musim kemarau genangan-genangan ini berupa sawah, kebun, dan hutan rawa (Gambar 4). 
Tabel 6. Beberapa kisaran parameter kualitas air danau, genangan, dan anak sungai di daerah aliran Sungai Batanghari, Jambi pada saat air banjir

Table 6. Water quality of lakes, floodplains, and rivers in Batanghari River basin at high water level of rainy seasons

\begin{tabular}{lcccccc}
\hline \multicolumn{1}{c}{ Parameter } & $\begin{array}{c}\text { Danau } \\
\text { Teluk }\end{array}$ & $\begin{array}{c}\text { Danau } \\
\text { Buluran } \\
\text { Kenali }\end{array}$ & $\begin{array}{c}\text { Danau } \\
\text { Kaos }\end{array}$ & $\begin{array}{c}\text { Sungai } \\
\text { Terap }\end{array}$ & $\begin{array}{c}\text { Sungai } \\
\text { Lubuk } \\
\text { Ruso }\end{array}$ & $\begin{array}{c}\text { Sungai } \\
\text { Pijoan }\end{array}$ \\
\hline Suhu air $(\mathrm{C})$ & $27-29$ & $27-30$ & $27-29$ & $27-29$ & $27-30$ & $27-29$ \\
Kecerahan air $(\mathrm{cm})$ & $15-47$ & $21-62$ & $30-65$ & $45-85$ & $35-76$ & $39-80$ \\
$\mathrm{Q}_{\text {terlarut }(\mathrm{mg} / \mathrm{l})}$ & $3,2-7,5$ & $2,1-6,7$ & $4,8-6,5$ & $3,3-6,9$ & $2,8-7,1$ & $4,8-6,7$ \\
$\mathrm{CQ}(\mathrm{mg} / \mathrm{l})$ & $1,5-2,9$ & $0,9-2,5$ & $0,1-2,9$ & $3-6,5$ & $0,3-6,5$ & $0,6-5,5$ \\
$\mathrm{pH}$ & $6,5-7$, & $6-7$ & $6,5-7$ & $5-6$ & $4,5-5,7$ & $5,5-7$, \\
$\mathrm{N}-\mathrm{Nh4}(\mathrm{mg} / \mathrm{l})$ & $0,04-0,09$ & $0,17-1$ & $0,12-0,70$ & $0,3-0,9$ & $0,2-0,5$ & $0,3 \backslash-0,7$ \\
\hline
\end{tabular}

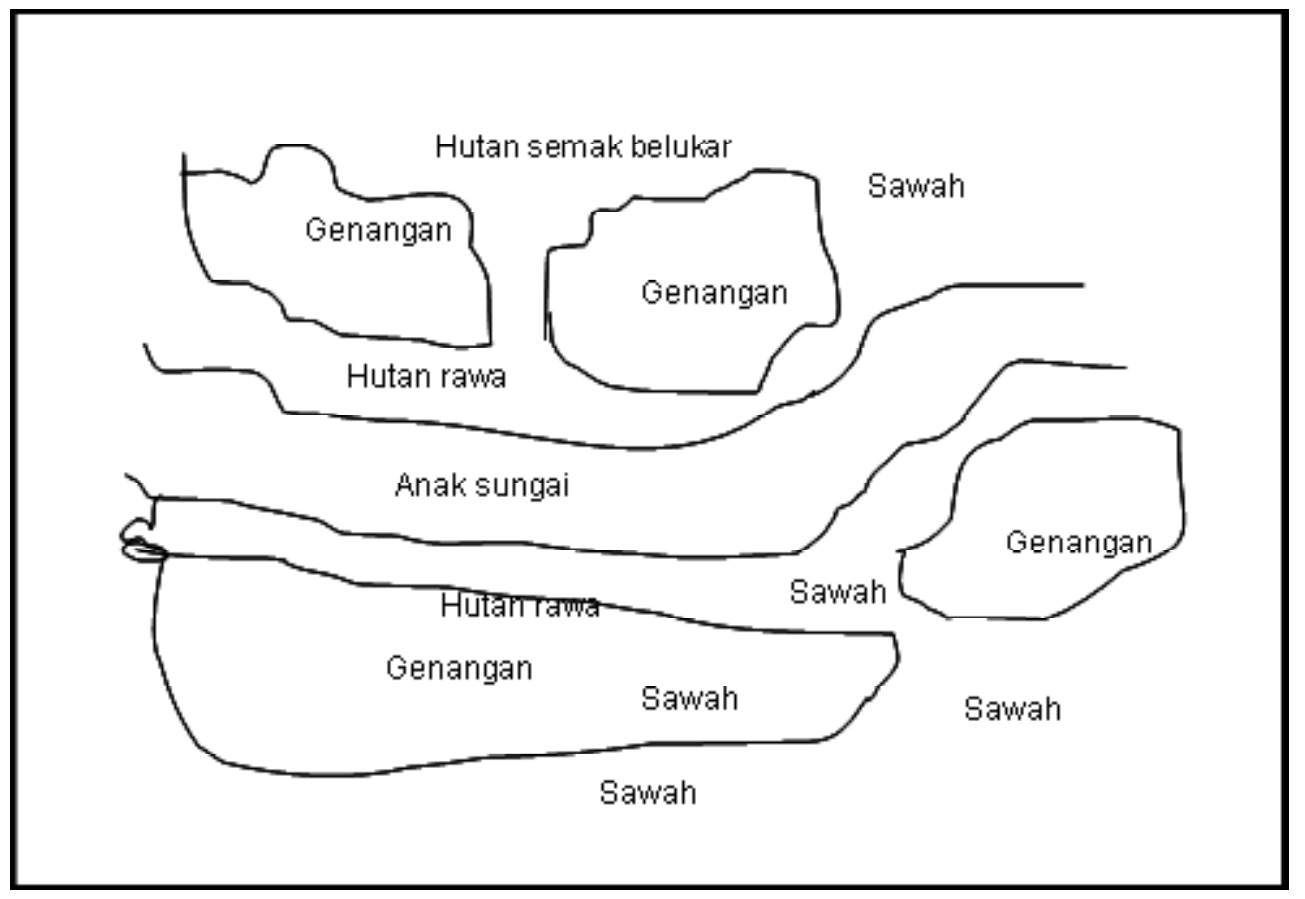

Gambar 4. Sketsa genangan-genangan banjiran yang terdapat di anak sungai yang merupakan habitat larva dan benih ikan pada musim penghujan.

Figure 4. The ploodplain sketch in river where serves for larva habitat and fish seed at rainy season.

Dari Tabel 6 dapat dilihat bahwa kandungan oksigen dan $\mathrm{pH}$ relatif lebih tinggi dibandingkan dengan kandungan oksigen dan $\mathrm{pH}$ pada saat air surut (Tabel 7). Fluktuasi air yang tinggi ini menyebabkan antara danau, anak-anak sungai, dan sungai utama saling berhubungan sehingga kualitas air hampir seragam antara Danau Teluk, Danau Buluran Kenali, Danau Kaos, Sungai Terap, Sungai Lubuk Ruso, dan Sungai Pijoan. Kondisi ini sangat menguntungkan untuk kelangsungan hidup dan pertumbuhan larva ikan di perairan tersebut. Pada saat dilakukan penelitian situasi ini berlangsung selama kurang lebih 3 minggu untuk kemudian air surut.
Pada saat air surut, kualitas air di beberapa lokasi kisaran sangat bervariasi, kecerahan air mencapai 15 $\mathrm{cm}$ (lokasi Danau Teluk) yang diakibatkan oleh banyak partikel-partikel yang tersuspensi. Kandungan $\mathrm{O}_{2}$ yang rendah, $\mathrm{CO}_{2}$ tinggi, dan amoniak tinggi diakibatkan ada percampuran air yang berasal dari daratan yang masuk ke perairan ketika terjadi air surut setelah banjir (Tabel 7). Nilai ini akan berangsur-angsur membaik setelah terjadi hujan atau udara cerah. kecerahan yang tinggi terjadi pada saat air telah benar-benar surut setelah 3 hari kemudian dan udara cerah, di mana pada saat ini kandungan oksigen mencapai 5,7 mg per I (Sungai 
Tabel 7. Beberapa kisaran parameter kualitas air danau, genangan, dan anak sungai di daerah aliran Sungai Batanghari, Jambi pada saat air surut setelah banjir

Table 7. Water quality of lakes, floodplains, and rivers in Batanghari River basin at low water level of rainy seasons

\begin{tabular}{lcccccc}
\hline \multicolumn{1}{c}{ Parameter } & $\begin{array}{c}\text { Danau } \\
\text { Teluk }\end{array}$ & $\begin{array}{c}\text { Danau } \\
\text { Buluran } \\
\text { Kenali }\end{array}$ & Danau Kaos & $\begin{array}{c}\text { Sungai } \\
\text { Terap }\end{array}$ & $\begin{array}{c}\text { Sungai } \\
\text { Lubuk Ruso }\end{array}$ & $\begin{array}{c}\text { Sungai } \\
\text { Pijoan }\end{array}$ \\
\hline Suhu air $\left(0^{\circ} \mathrm{C}\right)$ & $27-33$ & $27-30$ & $27-31$ & $27-29$ & $27-30$ & $27-29$ \\
Kecerahan $(\mathrm{cm})$ & $15-100$ & $31-92$ & $30-65$ & $45-85$ & $35-76$ & $39-85$ \\
$\mathrm{O}_{2}$ terlarut $(\mathrm{mg} / \mathrm{l})$ & $0,8-5,4$ & $2,1-4,7$ & $3,8-5,0$ & $2,3-4,9$ & $1,8-4,1$ & $3,8-5,7$ \\
$\mathrm{CO}_{2}(\mathrm{mg} / \mathrm{l})$ & $2,1-17,5$ & $2,9-11,5$ & $0,1-5,5$ & $3,0-16,5$ & $2,3-6,5$ & $3,0-10,5$ \\
$\mathrm{pH}$ & $5,5-6$ & $5-6$ & $5,5-6,5$ & $6,0-6,5$ & $5,5-6,0$ & $5,5-6,5$ \\
$\mathrm{~N}-\mathrm{Nh} 4(\mathrm{ppm})$ & $0,90-3,0$ & $0,17-1,0$ & $0,12-0,70$ & $0,3-2,0$ & $0,30-1,0$ & $0,3-2,0$ \\
\hline
\end{tabular}

Pijoan). Tinggi kandungan oksigen ini diduga diakibatkan angin yang kuat mengguncang air dan terjadi fotosintesis di perairan. Berdasarkan pada Pescod (1973) kualitas air pada saat air tinggi cukup baik bagi kehidupan ikan dan pada saat air surut kualitas air kurang mendukung kehidupan ikan sehingga pada saat surut ini benih-benih ikan melakukan ruaya menuju ke sungai utama.

\section{Penangkapan Benih Ikan}

Pada musim penghujan luas perairan umum beberapa kali lebih luas dibandingkan dengan musim kemarau dengan fluktuasi tinggi air berkisar antara 2,3 sampai dengan 6,68 m (Gambar 5). Dari Gambar 5 dapat dilihat bahwa permukaan perairan mulai naik dari bulan
September dan puncaknya terjadi pada bulan Desember sampai dengan Januari. Untuk selanjutnya, permukaan perairan mulai menurun pada bulan April, Mei, sampai dengan Juni.

Tinggi air sangat berpengaruh terhadap kehadiran benih ikan di perairan. Pada awal tinggi air yang terjadi pada akhir bulan September (Gambar 5) banyak tertangkap larva ikan ekonomis penting antara lain larva ikan jelawat, botia, lampam, baung, dan larva ikan lambak muncung. Penangkapan larva ikan dilakukan dengan alat tangkap tangguk (seminggu setelah air banjir, pada waktu tersebut tertangkap larva ikan jelawat dan larva ikan lain. Untuk lebih jelas, hasil tangkapan larva ikan dengan alat tangkap tangguk pada bulan September dapat dilihat pada Gambar 6.

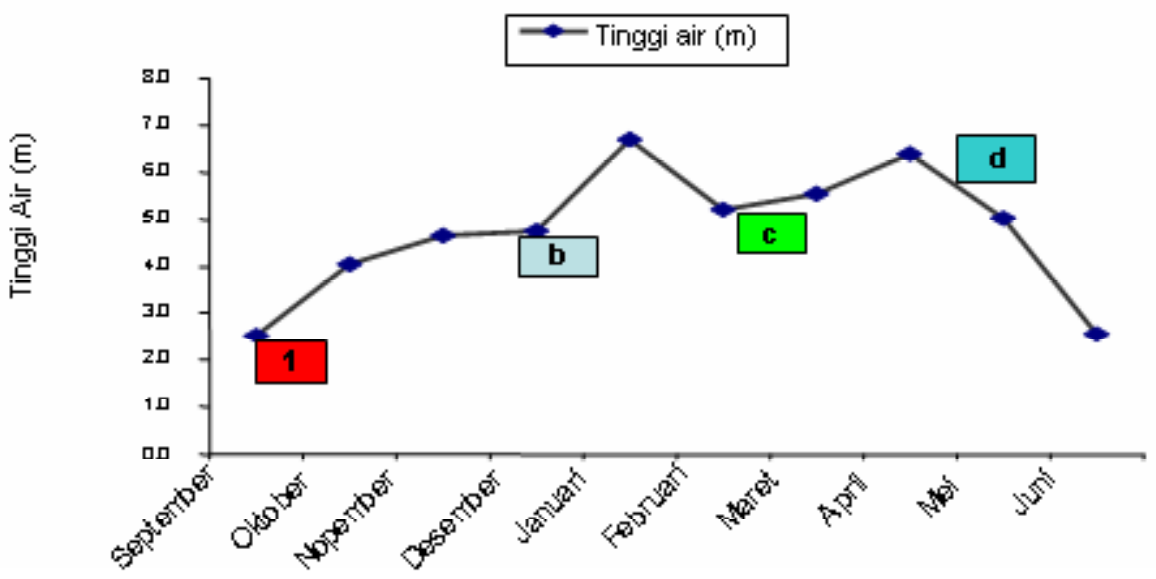

Gambar 5. Tinggi air di daerah aliran Sungai Batanghari, Jambi yang diukur dari bulan September 2000 sampai dengan Juni 2001.

Figure 5. Water fluctuation in Batanghari River region in September 2000 till June 2001.

Keterangan/Remarks: $\quad a=$ penangkapan larva ikan; $b=$ penangkapan benih ikan jelawat; $c=$ puncak penangkapan ikan hias (botia) dan benih ikan lain; $d=$ puncak penangkapan benih ikan ukuran jari (panjang 5 sampai dengan $8 \mathrm{~cm}$ ) 


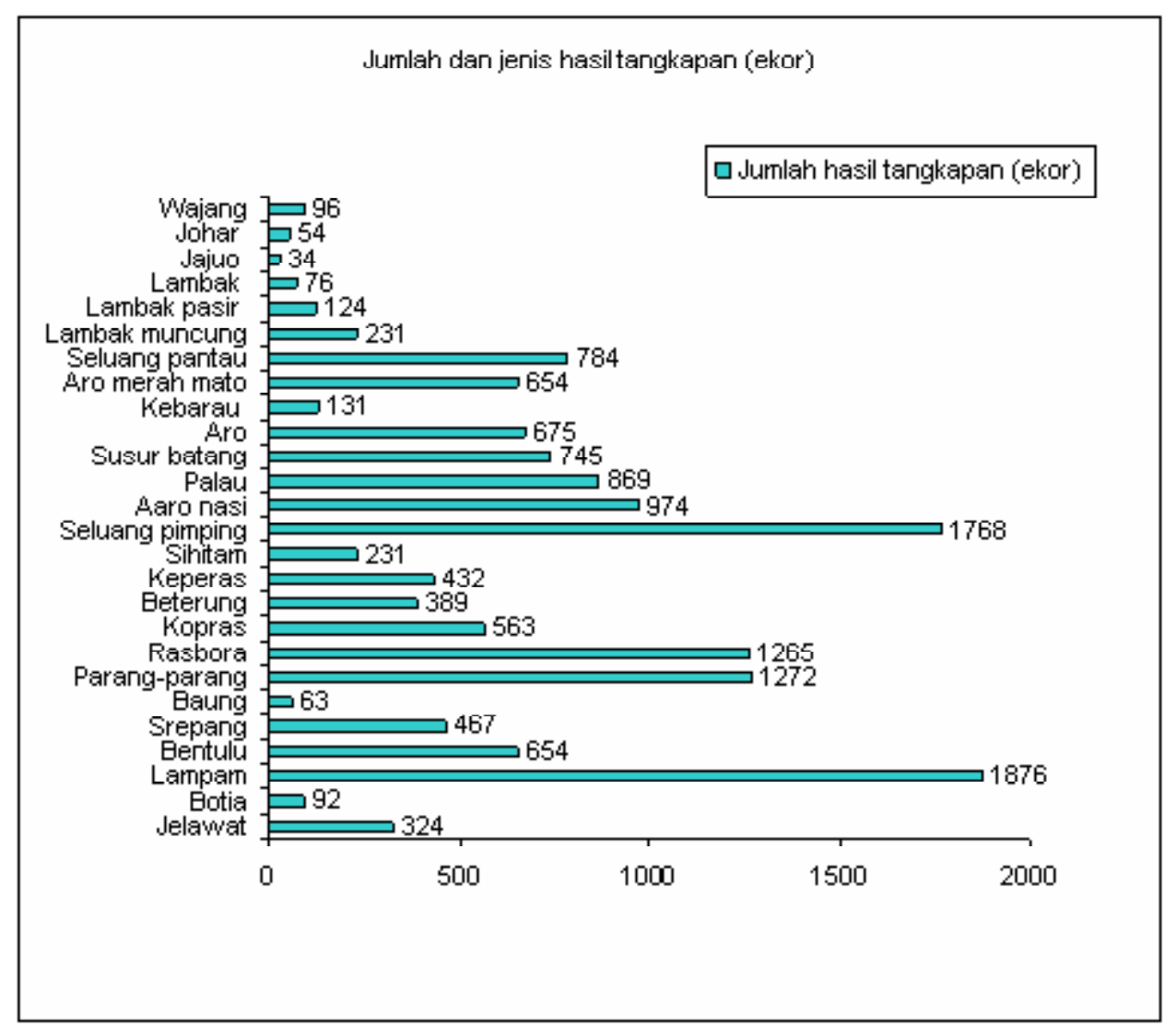

Gambar 6. Komposisi Jenis larva ikan dan jumlah hasil tangkapan tangguk pada tinggi air pertama di Danau Teluk, pada bulan September 2000.

Figure 6. Larvae fish composition and total catch of tangguk gear at the first height fluctuation water in Teluk Lake, in September 2000.

Dari Gambar 6 dapat dilihat bahwa penangkapan larva ikan terjadi pada bulan September. Tujuan penangkapan dari alat tangkap tangguk adalah penangkapan larva ikan jelawat dan jenis lain termasuk larva ikan botia dikembalikan ke perairan. Larva ikan botia tidak diambil karena dalam ukuran larva tidak diperdagangkan.

Penangkapan benih ikan terjadi pada saat air surut di bulan Desember dan alat tangkap yang digunakan sudah bervariasi yaitu alat tangkap tangkul, tabung tabok, tabam-tabam, dan rombong. Pada bulan Desember ini merupakan puncak penangkapan benih ikan jelawat. Pada saat air terjadi surut pada bulan Desember, larva ikan telah berukuran benih dengan panjang 2 sampai dengan $3 \mathrm{~cm}$. Nurdawati (1993) mengatakan bahwa penangkapan terhadap benih ikan jelawat dilakukan mulai dari ukuran larva sampai dengan ukuran jelejar. Pada saat dilakukan penelitian penangkapan ikan jelawat mulai dari ukuran larva sampai dengan jelejar (ukuran panjang 5 sampai dengan $8 \mathrm{~cm}$ ) dilakukan mulai dari bulan September sampai dengan April. Untuk lebih jelas, jenis-jenis benih ikan yang tertangkap dengan berbagai alat tangkap dapat dilihat pada Tabel 8. 
Tabel 8. Jenis-jenis benih ikan yang tertangkap dengan masing-masing alat tangkap di setiap lokasi pengamatan

Table $8 . \quad$ First fry species caught by each gear in location study site

\begin{tabular}{|c|c|c|c|c|c|c|c|}
\hline \multirow[b]{2}{*}{ No. } & \multirow[b]{2}{*}{ Jenis benih ikan } & \multicolumn{6}{|c|}{ Alat tangkap } \\
\hline & & Tangguk & Tabung & Rombong & Tangkul & Tabok & $\begin{array}{l}\text { Tabam- } \\
\text { Tabam }\end{array}$ \\
\hline 1. & Semua jenis larva & $x$ & & & $x$ & & $\mathrm{x}$ \\
\hline 2. & Botia, langli, susur batang & & $\mathrm{x}$ & & $x$ & & \\
\hline 3. & Lampam & $x$ & & & $x$ & $x$ & \\
\hline 4. & Semua jenis benih & & & & $x$ & & $x$ \\
\hline 5. & Baung lilin & & & & & & \\
\hline 6. & Caka-caka & & & & & & $x$ \\
\hline 7. & Tawon & & & & & & $x$ \\
\hline 8. & Coklat gurami & & & & $x$ & & $x$ \\
\hline 9. & serandang & & & & $x$ & & $x$ \\
\hline 10. & Toman & & & $\mathrm{x}$ & & & \\
\hline 11. & Tabun & & & & $x$ & & $x$ \\
\hline 12. & Ikan daun & & & & $x$ & & \\
\hline 13. & Putak & & & & $x$ & & $x$ \\
\hline 14. & Susur batang putih & & & & $x$ & & $x$ \\
\hline 15. & Strip enam/kadis & & & & $x$ & & $x$ \\
\hline 16. & Strip lima & & & & & & $x$ \\
\hline 17. & Lang Sumatera & & & & & & $x$ \\
\hline 18. & Sebarau lalat & & & & $x$ & & $x$ \\
\hline 19. & Sebaro hutan & & & & $x$ & & $x$ \\
\hline 20. & Srigunting & & & & $x$ & & \\
\hline 21. & Seluang segitiga & & & & $x$ & & \\
\hline 22. & Seluang ridik & & & & $x$ & & \\
\hline 23. & Tali-tali & & & & $x$ & & \\
\hline 24. & Tali-tali & & & & $x$ & & $\mathrm{x}$ \\
\hline 25. & Lais kaca & & & & $x$ & & $x$ \\
\hline 26. & Lais kaca & & & & $x$ & & $x$ \\
\hline 27. & Lalayang & & & & $x$ & & $x$ \\
\hline 28. & Baung kembang & & & & $x$ & $x$ & $x$ \\
\hline 29. & Baung murai & & & & $x$ & $x$ & $x$ \\
\hline 30. & Ringo & $x$ & & & $x$ & & $x$ \\
\hline
\end{tabular}

Puncak penangkapan benih ikan botia dan benih ikan lain terjadi pada bulan Pebruari. Pada bulan ini hampir semua jenis benih ikan tertangkap dengan berbagai alat tangkap, kecuali benih ikan botia hanya tertangkap dengan alat tangkap tabung dan tangkul. Dinas Perikanan Tingkat I Jambi (1992) mengatakan bahwa hubungan antara kelimpahan produksi ikan hias dengan fluktuasi permukaan air Sungai Batanghari cenderung ditentukan oleh kombinasi antara ketinggian air maksimum dan lama air bertahan pada ketinggian tersebut. Ini dapat dilihat pada Gambar 5. Tinggi air tertinggi (melimpah tebing) terjadi pada bulan Januari dan menurun pada bulan
Pebruari dan jumlah ikan botia yang tertangkap pada bulan Pebruari jauh lebih tinggi dibandingkan dengan bulan Oktober, Desember, dan Maret (Gambar 7).

Pola penangkapan benih ikan lain hampir sama dengan pola penangkapan ikan botia yaitu tertangkap pada saat air mulai surut dan hasil tangkapan tinggi terjadi pada hari ke- 5 sampai dengan ke-10 kemudian menurun pada hari ke-10 sampai dengan ke-12. Hal ini, disebabkan oleh benih-benih ikan telah beruaya ke luar dari danaudanau dan anak-anak sungai menuju sungai utama. 

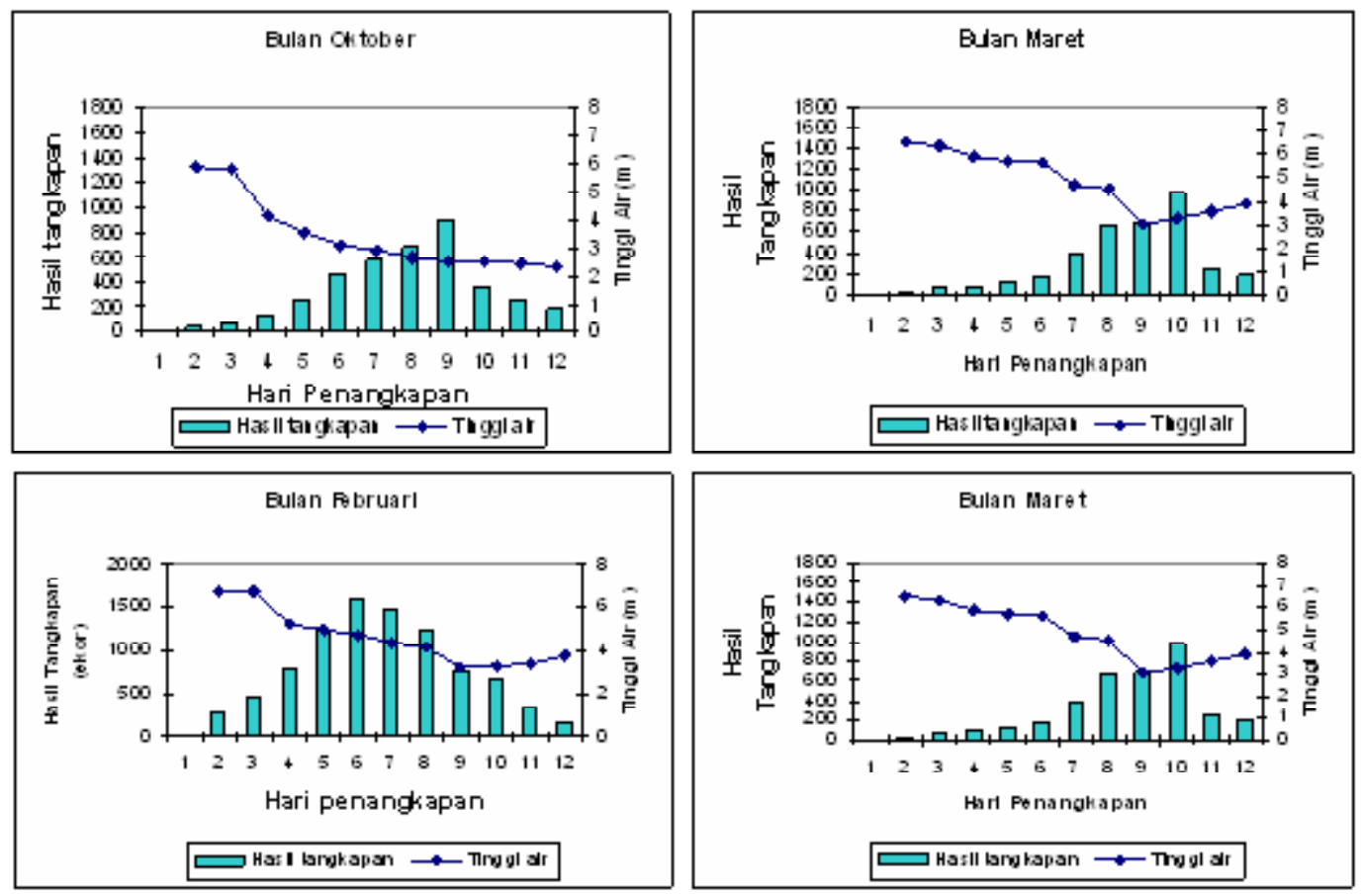

Gambar 7. Hasil tangkapan ikan botia (Cromobotia macracanthus) dengan alat tangkap tabung (per 100 buah tabung) pada bulan Oktober, Desember, Pebruari, dan Maret di Danau Kaos.

Figure 7. The catch of Cromobotia macracanthus with tabung (trap) in October, Desember, Februari, and March in Kaos Lake.

Puncak penangkapan benih ikan ukuran jari (panjang 5 sampai dengan $8 \mathrm{~cm}$ ) terjadi pada bulan April. Benih ukuran jari banyak tertangkap dengan alat tangkap tangkul yang dilakukan di anak-anak sungai yang menghubungkan danau-danau dengan sungai utama dan di muara-muara anak-anak sungai.

\section{KESIMPULAN}

1. Benih ikan yang ditemukan di daerah aliran Sungai Batanghari adalah 90 jenis yang termasuk ke dalam 47 genus, 19 famili, 5 sub ordo dari Ordo Perciformes (Percoidei, Gobioidei, Anabantoidei, Channoidei, dan Mastacembeloidei) dan 6 Ordo (Osteoglosiformes, Cypriniformes, Siluriformes, Perciformes, Cyprinodontiformes, dan Tetraodontiformes).

2. Famili Cyprinidae mendominasi jenis yang ditemukan yaitu 40 jenis, diikuti oleh Famili Bagridae 15 jenis. Dari 90 jenis benih ikan yang ditemukan, 38 jenis antara lain merupakan ikan hias yang telah diperdagangkan secara nasional dan internasional.

3. Distribusi larva ikan di pinggir-pinggir genangan pada waktu musim penghujan dan ke luar dari habitat anakan pada saat air surut setelah banjir. Danau Teluk,
Danau Buluran Kenali, Danau Kaos, Sungai Terap, Sungai Lubuk Ruso, dan Sungai Pijoan merupakan habitat sementara benih ikan di mana setelah kualitas air menurun benih ikan melakukan ruaya menuju ke sungai utama dan seterusnya beruaya ke bagian hulu sungai.

4. Kualitas air di lokasi penelitian menunjukkan kondisi yang baik untuk kehidupan benih ikan pada waktu air banjir dan kualitas air menurun pada saat air surut setelah banjir.

\section{DAFTAR PUSTAKA}

APHA. 1986. Standard methods for the examinations of water and wastewater. APHA inc. Washington DC.

Dinas Perikanan Propinsi Jambi. 1983. Laporan tahunan Dinas Perikanan Tingkat Propinsi. 69 hal.

Dinas Perikanan Propinsi Jambi. 1984. Laporan survei pemasaran ikan hias Propinsi Daerah Tingkat I Jambi. $58 \mathrm{hal}$.

Dinas Perikanan Propinsi Jambi. 1989. Buku tahunan statistik perikanan Tingkat Propinsi Jambi. 73 hal. 
Dinas Perikanan Propinsi Jambi. 1993. Studi identifikasi atau inventarisasi plasma nutfah perikanan perairan umum Jambi. 119 hal.

Dinas Perikanan Tingkat I Jambi. 1992. Pengelolaan dan pemanfaatan perairan umum di Propinsi Jambi. Prosiding Temu Karya IImiah Perikanan Perairan Umum. Pengkajian Potensi dan Prospek Pengembangan Perairan Umum Sumatera bagian Selatan. Badan Penelitian dan Pengembangan Pertanian. Pusat Penelitian dan Pengembangan Perikanan. Departemen Pertanian. Hal.68-80.

Kottelat, M. \& A. J. Whitten with S. Kartikasari \& S. Wijoatmodjo. 1993. Fresh water fishes of western Indonesia and Sulawesi. Periplus Editions Limited. $434 \mathrm{p}$.

Nurdawati, S. 1993. Eksploitasi bubuk ikan (fry) jelawat (Leptobarbus hoeveni Blkr) di perairan umum Jambi. Warta Penelitian dan Pengembangan Pertanian. Vol.XV No.5. 8-9.

Nurdawati, S. \& E. Dharyati. 1994. Catatan tentang beberapa jenis ikan hias dan habitatnya di perairan umum Jambi. Buletin Penelitian Perikanan Darat. Vol.12 No.2. 66-71.

Nurdawati, S. \& A. Said. 1995a. Inventarisasi ikan hias di beberapa perairan Sungai Batanghari, Jambi. Kumpulan Makalah Seminar Penyusunan, Pengolahan, dan Evaluasi Hasil Penelitian Perikanan Perairan Umum. Sub Balai Penelitian Perikanan Air Tawar. Pusat Penelitian dan Pengembangan Perikanan. Badan Penelitian dan Pengembangan Pertanian. Departemen Pertanian. Hal.192-197.

Nurdawati, S. \& A. Said. 1995b. Pengaruh alat tangkap tabung dan kedalaman operasi terhadap hasil tangkapan ikan hias di Danau Teluk, Jambi. Kumpulan Makalah Seminar Penyusunan, Pengolahan, dan Evaluasi Hasil Penelitian Perikanan Perairan Umum. Sub Balai Penelitian Perikanan Air Tawar. Pusat Penelitian dan Pengembangan Perikanan. Badan Penelitian dan Pengembangan Pertanian. Departemen Pertanian. Hal.178-181.

Nurdawati, S. 2006. Peranan ekosistem hutan rawa Danau Cala di Kabupaten Musi Banyuasin sebagai habitat ikan perairan umum. Seminar Nasional Pengelolaan Hutan dan Lahan Rawa secara Bijaksana dan Terpadu. Balai Penelitian dan
Pengembangan Hutan Tanaman. Badan Penelitian dan Pengembangan Kehutanan. Departemen Kehutanan. Hal.143-149.

Ondara. 1968. Survei benih kelemak. Lembaga Penelitian Perikanan Darat Cabang Palembang. 22 hal.

Pescod. 1973. Investigation of rational effluent and stream standart for tropical countries. Environmental Engineering Division. Asian Inst. Tech. Bangkok. 59 p.

Saanin, H. 1968. Taksonomi dan kunci identifikasi ikan. Vol.I dan II. Bina Cipta. Bandung.

Schuster, W. H. \& R. R. Djajadiredja. 1952. Local common names of Indonesian fishes. Van HooveBandung, S'-Gravenhage.

Setiawan, I. E. 2002. Umur rekruitmen dan pertumbuhan stadia elver ikan sidat Aguilla marmorata berdasarkan mikrostruktur otolith. Jurnal Sains dan Teknologi Indonesia. Vol.4 No.5. 26-31.

Sriati \& Sulistiono. 2000. Population structure and abundance of elver (Oell juvenile) of Anguilla bicolor in Cimandirii Riverbank, Indonesia. JSPS-DGHE International Symposium Sustainable Fisheries in Asia in the New Millenium. 326-330.

Utomo, A. D. \& Z. Nasution. 1995. Potensi sumber daya perikanan di beberapa daerah aliran Sungai Batanghari, Jambi. Kumpulan Makalah Seminar Penyusunan, Pengolahan, dan Evaluasi Hasil Penelitian Perikanan Perairan Umum. Sub Balai Penelitian Perikanan Air Tawar. Pusat Penelitian dan Pengembangan Perikanan. Badan Penelitian dan Pengembangan Pertanian. Departemen Pertanian. Hal.159-166.

Utomo, A. D. \& Asyari. 1999. Peranan ekosistem hutan rawa air tawar bagi kelestarian sumber daya perikanan di Sungai Kapuas, Kalimantan Barat. Jurnal Penelitian Perikanan Indonesia. Vol.5 (3). 1-14.

Wagiyo, K., E. S. Girsang, \& Yulianti. 2001. Sediaan larva ikan dan karakteristik lingkungannya di perairan Bengkalis. Prosiding Seminar Nasional Keanekaragaman Hayati Ikan. 179-184.

Weber, M. \& I. F. de Beaufort. 1913-1953. The fishes of Indonesia Australian archipelago. Vol.Il-X. E. J. Brill. Leiden. 
Lampiran 1. Jenis benih ikan dan penyebaran di Danau Teluk, Danau Buluran Kenali, Danau Kaos, Sungai Terap, Sungai Lubuk Ruso, dan Sungai Pijoan

Appendix 1. $\quad$ Fish fry species and its distribution in Teluk Lake, Buluran Kenali Lake, Kaos Lake, Terap River, Lubuk Ruso River, and Pijoan River

\begin{tabular}{|c|c|c|c|c|c|c|c|c|}
\hline No. & $\begin{array}{l}\text { Jenis benih } \\
\text { Nama lokal }\end{array}$ & Nama ilmiah & $\begin{array}{l}\text { Danau } \\
\text { Teluk }\end{array}$ & $\begin{array}{l}\text { Danau } \\
\text { Buluran } \\
\text { Kenali }\end{array}$ & $\begin{array}{c}\text { Danau } \\
\text { Kaos }\end{array}$ & $\begin{array}{l}\text { Sungai } \\
\text { Terap }\end{array}$ & $\begin{array}{l}\text { Sungai } \\
\text { Lubuk } \\
\text { Ruso }\end{array}$ & $\begin{array}{l}\text { Sungai } \\
\text { Pijoan }\end{array}$ \\
\hline 1. & Putak & Notopterus notopterus & & & & $x$ & $x$ & $x$ \\
\hline 2. & Mentulu & Barbichthys laevis & $x$ & $x$ & $x$ & & & \\
\hline 3. & Lampam/kepiat & $\begin{array}{l}\text { Barbodes } \\
\text { schwanenfeldii }\end{array}$ & $x$ & $x$ & $x$ & & & $x$ \\
\hline 4. & Seluang terbang & Chela laubuca & & & & $x$ & & \\
\hline 5. & Seluang pimping & Chela maassi & & & & $x$ & $x$ & $x$ \\
\hline 6. & Seluang pimping & $\begin{array}{l}\text { Parachela } \\
\text { oxygastroides }\end{array}$ & $x$ & $x$ & $x$ & & & \\
\hline 7. & Susur batang putih & $\begin{array}{l}\text { Crossocheilus } \\
\text { gnathopogon }\end{array}$ & $x$ & $x$ & $x$ & & & \\
\hline 8. & Wajang & $\begin{array}{l}\text { Cyclocheillichthys } \\
\text { enoplos }\end{array}$ & $x$ & $x$ & $x$ & & & \\
\hline 9. & Kopras & $\begin{array}{l}\text { Cyclocheillichthys } \\
\text { apogon }\end{array}$ & $x$ & $x$ & $x$ & & & \\
\hline 10. & Keperas & $\begin{array}{l}\text { Cyclocheilichthys } \\
\text { heteronema }\end{array}$ & $x$ & $x$ & $x$ & $x$ & $x$ & $x$ \\
\hline 11. & Kopras & $\begin{array}{l}\text { Cyclocheilichthys } \\
\text { armatus }\end{array}$ & $x$ & $x$ & $x$ & $x$ & $x$ & $x$ \\
\hline 12. & Susur batang & $\begin{array}{l}\text { Epalzeorhynchus } \\
\text { kallopterus }\end{array}$ & $\mathrm{x}$ & $x$ & $x$ & & & $x$ \\
\hline $\begin{array}{l}13 . \\
14 .\end{array}$ & $\begin{array}{l}\text { Sebarau lalat } \\
\text { Kebarau }\end{array}$ & $\begin{array}{l}\text { Hampala ampalong } \\
\text { Hampala } \\
\text { macrolepidota }\end{array}$ & $x$ & $x$ & $x$ & & $x$ & \\
\hline 15. & Si hitam & $\begin{array}{l}\text { Labeo } \\
\text { chrysophekadion }\end{array}$ & $x$ & $x$ & $x$ & & & \\
\hline 16. & Kelemak & Leptobarbus hoevenii & $x$ & $x$ & $x$ & & & $x$ \\
\hline 17. & Lambak muncung & Labiobarbus ocellatus & $x$ & $x$ & $x$ & & & \\
\hline 18. & Lambak pasir & Labiobarbus festivus & $x$ & $x$ & $x$ & & & \\
\hline 19. & lambak & Labiobarbus kuhlii & $x$ & $x$ & $x$ & & & \\
\hline 20. & Jajuo & Luciosoma trinema & & & & & $x$ & $x$ \\
\hline 21. & Johar & Luciosoma setigerum & $x$ & $x$ & $x$ & & & \\
\hline 22. & Parang-parang & $\begin{array}{l}\text { Macrochirichthys } \\
\text { macrochirus }\end{array}$ & $x$ & $x$ & $x$ & & & \\
\hline 23. & Sebaro hutan & Rasbora kalochroma & & & & $x$ & & \\
\hline 24. & Srigunting & R. caudimaculata & & & & $x$ & & \\
\hline 25. & Seluang segitiga & R. heteromorpha & & & & $x$ & & \\
\hline 26. & Seluang ridik & R. dorsiocellata & & & & & $x$ & \\
\hline 27. & Seluang biaso & R. dusonensis & & & & & $x$ & \\
\hline 28. & Teri & Rasbora sp. & $x$ & & & & $x$ & \\
\hline 29. & Seluang pantau & Rasbora argyrotaenia & $x$ & $x$ & $x$ & $x$ & $x$ & $x$ \\
\hline 30. & Strip enam/kadis & Puntius johorensis & & & & & $x$ & \\
\hline
\end{tabular}


Lampiran 1. Lanjutan

Appendix 1. Continues

\begin{tabular}{|c|c|c|c|c|c|c|c|c|}
\hline No. & $\begin{array}{l}\text { Jenis benih } \\
\text { Nama lokal }\end{array}$ & Nama ilmiah & $\begin{array}{l}\text { Danau } \\
\text { Teluk }\end{array}$ & $\begin{array}{c}\text { Danau } \\
\text { Buluran } \\
\text { Kenali }\end{array}$ & $\begin{array}{l}\text { Danau } \\
\text { Kaos }\end{array}$ & $\begin{array}{l}\text { Sungai } \\
\text { Terap }\end{array}$ & $\begin{array}{l}\text { Sungai } \\
\text { Lubuk } \\
\text { Ruso }\end{array}$ & $\begin{array}{l}\text { Sungai } \\
\text { Pijoan }\end{array}$ \\
\hline 31. & Strip lima & Puntius pentazona & & & & & $x$ & $x$ \\
\hline 32. & Seluang payo & Puntius lineatus & & & & $x$ & & \\
\hline 33. & $\begin{array}{l}\text { Seluang } \\
\text { maram }\end{array}$ & Puntius eugrammus & & & & & $x$ & \\
\hline 34. & Elang & Puntius tetrazona & $x$ & $x$ & $x$ & & & $x$ \\
\hline 35. & Srepang & $\begin{array}{l}\text { Puntioplites } \\
\text { waandersii }\end{array}$ & $x$ & $x$ & $x$ & & & \\
\hline 36. & Aro & $\begin{array}{l}\text { Osteochilus } \\
\text { borneensis }\end{array}$ & $x$ & $x$ & $x$ & & & \\
\hline 37. & $\begin{array}{l}\text { Aro merah } \\
\text { mato }\end{array}$ & $\begin{array}{l}\text { Osteochilus } \\
\text { melanopleura }\end{array}$ & $x$ & $x$ & $x$ & & & \\
\hline 38. & Aro nasi & Osteochilus schlegeli & $x$ & $x$ & $x$ & & & \\
\hline 39. & Palau & Osteochilus hasseltii & $x$ & $x$ & $x$ & & & \\
\hline 40. & Teri & $\begin{array}{l}\text { Rasborichthys } \\
\text { helfrichii }\end{array}$ & $x$ & & & & & \\
\hline 41. & Ringo & $\begin{array}{l}\text { Thynnichthys } \\
\text { thynnoides }\end{array}$ & $x$ & & & & & $x$ \\
\hline 42. & Lambak pipih & $\begin{array}{l}\text { Thynnichthys } \\
\text { polylepis }\end{array}$ & $x$ & $x$ & $x$ & & & $x$ \\
\hline 43. & Ikan merah & Botia macracanthus & $x$ & $x$ & $x$ & & & $x$ \\
\hline 44. & Langli hijau & Botia hymenophysa & $x$ & $x$ & $x$ & & & $x$ \\
\hline 45. & Tali-tali & $\begin{array}{l}\text { Acantopsis } \\
\text { octoactinotus }\end{array}$ & & & & $x$ & $x$ & $x$ \\
\hline 46. & Tali-tali & $\begin{array}{l}\text { Acanthophthalmus } \\
\text { shelfordii }\end{array}$ & & & & $x$ & & \\
\hline 47. & Tali-tali & $\begin{array}{l}\text { Acanhtopthalmus } \\
\text { anguillaris }\end{array}$ & & & & $x$ & & \\
\hline 48. & Sengarat & $\begin{array}{l}\text { Belodontichthys } \\
\text { dinema }\end{array}$ & $x$ & & & & & $x$ \\
\hline 49. & Lais kuning & $\begin{array}{l}\text { Kryptopterus } \\
\text { schilbeides }\end{array}$ & $x$ & $x$ & & $x$ & $x$ & $x$ \\
\hline 50. & Lais tapa & $\begin{array}{l}\text { Ompok } \\
\text { hypophthalmus }\end{array}$ & $x$ & $x$ & $x$ & & & $x$ \\
\hline 51. & Lais kaca & Kryptopterus bicirrhis & & & & $x$ & $x$ & $x$ \\
\hline 52. & Lais & $\begin{array}{l}\text { Kryptopterus } \\
\text { mononema }\end{array}$ & & & & $x$ & $x$ & $x$ \\
\hline 53. & Lais & $\begin{array}{l}\text { Kryptopterus } \\
\text { hexapterus }\end{array}$ & $x$ & $x$ & $x$ & $x$ & $x$ & $x$ \\
\hline 54. & Lais hujan & $\begin{array}{l}\text { Kryptopterus } \\
\text { palembangensis }\end{array}$ & $x$ & $x$ & $x$ & $x$ & $x$ & $x$ \\
\hline 55. & Lais tima & Kryptopterus apogon & $x$ & $x$ & $x$ & $x$ & $x$ & $x$ \\
\hline 56. & Lais kaca & Kryptopterus minor & & & & $x$ & $x$ & $x$ \\
\hline 57. & Lalayang & $\begin{array}{l}\text { Bagrichthys } \\
\text { hyselopterus }\end{array}$ & & & & $x$ & $x$ & $x$ \\
\hline 58. & Baung lilin & Mystus bimaculatus & & & & & $x$ & $\mathrm{x}$ \\
\hline $\begin{array}{l}59 . \\
60 .\end{array}$ & $\begin{array}{l}\text { Senggiring } \\
\text { Senggiring }\end{array}$ & $\begin{array}{l}\text { Mystus singaringan } \\
\text { Mystus microcantus }\end{array}$ & $x$ & $\begin{array}{l}x \\
x\end{array}$ & $\begin{array}{l}x \\
x\end{array}$ & $\begin{array}{l}x \\
x\end{array}$ & $\begin{array}{l}x \\
x\end{array}$ & $\begin{array}{l}x \\
x\end{array}$ \\
\hline
\end{tabular}


Lampiran 1. Lanjutan

Appendix 1. Continues

\begin{tabular}{|c|c|c|c|c|c|c|c|c|}
\hline No. & $\begin{array}{l}\text { Jenis benih } \\
\text { Nama lokal }\end{array}$ & Nama ilmiah & $\begin{array}{l}\text { Danau } \\
\text { Teluk }\end{array}$ & $\begin{array}{c}\text { Danau } \\
\text { Buluran } \\
\text { Kenali }\end{array}$ & $\begin{array}{l}\text { Danau } \\
\text { Kaos }\end{array}$ & $\begin{array}{l}\text { Sungai } \\
\text { Terap }\end{array}$ & $\begin{array}{l}\text { Sungai } \\
\text { Lubuk } \\
\text { Ruso }\end{array}$ & $\begin{array}{l}\text { Sungai } \\
\text { Pijoan }\end{array}$ \\
\hline 61. & Baung & Hemibagrus nemurus & $x$ & $x$ & $x$ & $x$ & $x$ & $x$ \\
\hline 62. & $\begin{array}{l}\text { Baung } \\
\text { kembang }\end{array}$ & $\begin{array}{l}\text { Leiocassis } \\
\text { leiacanthus }\end{array}$ & & & & $x$ & $x$ & $x$ \\
\hline 63. & Baung murai & Leiocassis stenomus & & & & $x$ & $x$ & $x$ \\
\hline 64. & Caka-caka & Chaca bankanensis & & & & $x$ & $x$ & $x$ \\
\hline 65. & Riu & Laides hexanema & $x$ & $x$ & $x$ & & & \\
\hline 66. & Kaca-kaca & Parambassis wolffii & $x$ & $x$ & $x$ & & & \\
\hline 67. & Kaca-kaca & $\begin{array}{l}\text { Parambassis } \\
\text { punctulata }\end{array}$ & $x$ & $x$ & $x$ & & & \\
\hline 68. & Tabun & Nandus nebulosus & & & & $x$ & $x$ & $x$ \\
\hline 69. & Ikan daun & N. Nandus & & & & $x$ & $x$ & $x$ \\
\hline 70. & Beterung & Pristolepis fasciata & $x$ & $x$ & $x$ & & & \\
\hline 71. & Beterung & Pristolepis grootii & & & $x$ & $x$ & $x$ & \\
\hline 72. & Sumpit & Toxotes jaculator & $x$ & $x$ & $x$ & & & \\
\hline 73. & Tawon & Brachygobius doriae & & & & $x$ & $x$ & $x$ \\
\hline 74. & Tempalo & Betta anabatoides & & & & $x$ & $x$ & $x$ \\
\hline 75. & Tempalo & Betta picta & & & & $x$ & $x$ & $x$ \\
\hline 76. & Tempalo & Betta taeniata & & & & $x$ & $x$ & $x$ \\
\hline 77. & Cupang & Trichopsis vittata & $x$ & $x$ & $x$ & $x$ & $x$ & $x$ \\
\hline 78. & Coklat gurami & $\begin{array}{l}\text { Spaerichthys } \\
\text { osphromenoides }\end{array}$ & & & & $x$ & $x$ & $x$ \\
\hline 79. & Sepat leeri & Trichogaster leerii & $x$ & $x$ & $x$ & $x$ & $x$ & $x$ \\
\hline 80. & Tembakang & Helostoma temminckii & $x$ & $x$ & $x$ & $x$ & $x$ & $x$ \\
\hline 81. & Kalui & Osphronemus goramy & $x$ & $x$ & $x$ & & $x$ & $x$ \\
\hline 82. & Selincah & Belontia hasselti & & & & $x$ & $x$ & \\
\hline 83. & Gabus & Channa striata & $x$ & $x$ & $x$ & $x$ & $x$ & $x$ \\
\hline 84. & Bujuk & Channa lucius & $x$ & $x$ & $x$ & $x$ & & \\
\hline 85. & Toman & Channa micropeltes & $x$ & $x$ & $x$ & & & \\
\hline 86. & Serandang & $\begin{array}{l}\text { Channa } \\
\text { pleurophthalmus }\end{array}$ & & & $x$ & $x$ & & \\
\hline 87. & Tilan & $\begin{array}{l}\text { Mastacembelus } \\
\text { erythrotaenia }\end{array}$ & & & & $x$ & $x$ & $x$ \\
\hline 88. & Tilan putih & $\begin{array}{l}\text { Macrognathus } \\
\text { aculeatus }\end{array}$ & & & & $x$ & $x$ & $x$ \\
\hline 89. & Buntal & $\begin{array}{l}\text { Tetraodon } \\
\text { palembangensis }\end{array}$ & $x$ & $x$ & $x$ & & & \\
\hline 90. & Julung-julung & $\begin{array}{l}\text { Xenentodon } \\
\text { canciloides }\end{array}$ & $x$ & $x$ & $x$ & & & \\
\hline
\end{tabular}

